\title{
Sedimentary geology in Poland - a tribute to Piotr Roniewicz Part 1
}

This issue of Geological Quarterly is dedicated to Professor Piotr Roniewicz on the occasion of his 80th birthday, and the authors of the papers - former students, collaborators and admirers (often all three at once) - decided to express their appreciation for his achievements and his role in the sedimentology. The issue has a subtitle "Part 1", as "Part 2" will be published later this year.

Piotr Roniewicz was born and educated in Warszawa. He completed his university studies at the Faculty of

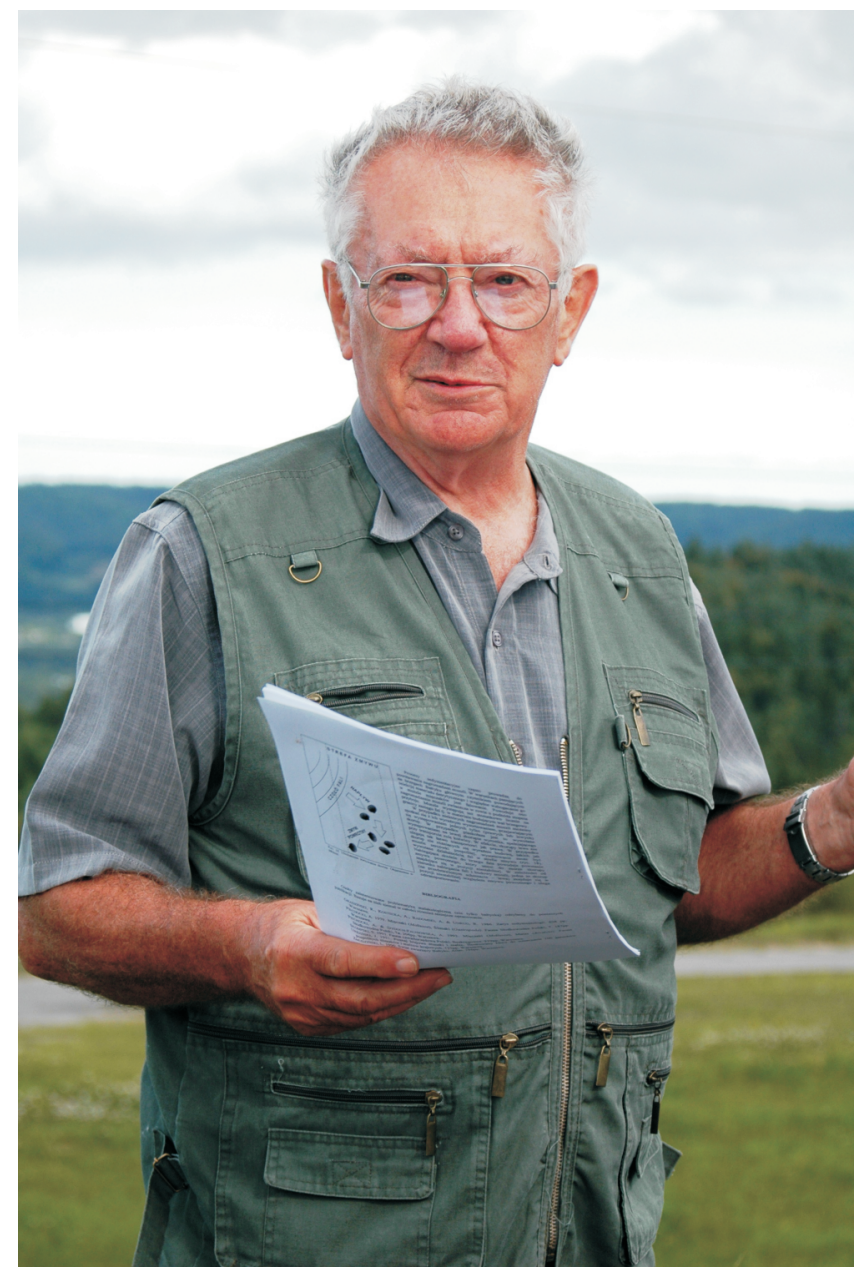

Piotr Roniewicz giving a short lecture during the student's field course "Present-day coastal processes of the Baltic Sea and their sedimentary record" (September, 2005).

Photo by A. Wysocka
Geology of the University of Warsaw in 1959, gaining the M.Sc., and began his geological career at the Faculty. He worked there until his retirement in 2006, and in 1984-1990 he was the Dean of Faculty (previously, in 1981-1984, Vice-Dean).

His doctoral thesis (1964) dealt with the siliciclastic deposits of early Triassic age in the Tatra Mts. and was supervised by Professor E. Passendorfer; the thesis was then published in Acta Geologica Polonica, 16. In 1969, he received a D.Sc. degree based on his thesis dealing with sedimentation of the Nummulite Eocene in the Tatra Mts. (published in Acta Geologica Polonica, 19). In 1980, he received the scientific title of professor. During his academic years, he supervised many M.Sc. theses and doctoral theses, and his educational achievements went hand in hand with successful organizational, publication and expertise activities. Those educational achievements have not been restricted to the university, but also to general public, as Professor P. Roniewicz dedicated much effort to popularizing the Earth sciences in various communication media: radio, TV, and movies.

Most of his process-oriented publications are fine sedimentological analyses of various sedimentary formations formed in marine, transitional marine-continental, and continental environments in Poland and adjacent countries. However, there are also very important papers referring to modern sedimentary environments (such as the paper The Tasman Sea coastal-zone sedimentary model, N.S.W., Australia, published in Acta Geologica Polonica, 34), origin of bedforms, hardgrounds, trace fossils or submarine slumping.

The content of this issue commemorating his jubilee reflects his wide scientific interests and achievements, and the order of the papers included follows the evolution of his scientific interests.

The first six papers of this issue deal with the Carpathian region; as already mentioned, the Central Carpathians were the place where Piotr Roniewicz began his scientific career. M. Łoziński et al. describe varied anisotropy of magnetic susceptibility (AMS) fabrics within a fine-grained terrestrial sedimentary sequence of the Orava-Nowy Targ Basin. A. Jezierska and P. Łuczyński characterize Jurassic unconformities in the High-Tatric succession in the Tatra Mountains, and M. Gradziński et al. present new data on pre-Eocene karst in the Tatra Mountains. P. Łapcik et al. present the result of study of deep-sea mass-flow sediments and their exotic blocks from the Ropianka Formation (Campanian-Paleocene) in the Skole Nappe, that indicates the distance of the mass flows being at least 25-97 km from the shelf edge. $B$. Studencka et al. describe an intriguing bivalve fauna derived from the Oligocene Menilite Beds of the Silesian 
Nappe, Polish Outer Carpathians, that is typical for the Solenovian of the Paratethyan Euxine-Caspian Basin System, and A. Kaczmarek et al. conclude, based on the calcareous nannoplankton study, the Early Miocene age of the Stare Bystre Formation (Magura Nappe, Outer Carpathians, Poland).

Eight papers that follow refer to various problems of recent sedimentary geology. J. Wojewoda et al. present regional implications of synsedimentary seismotectonic features in Triassic and Cretaceous sediments of the Intrasudetic Basin, M. Kozłowska et al. characterize a new Triassic-Jurassic section in the southern part of the Holy Cross Mts., which has important implications for palaeogeography, and $P$. Leonowicz presents tubular tempestites from southern Poland and their application for environmental and sequence stratigraphy interpretation. Z. Csiki-Sava et al. described the Hettangian tetrapod burrows from the continental Steierdorf Formation at Anina, western Romania.

S. Rudowski et al. document submarine landslides on the slope of a sandy barrier in the Hel Peninsula (Southern Baltic), and K. Rotnicki et al. present data indicating a palaeotsunami on the southern coast of the Baltic Sea. Two papers analyse the distribution of rare earth elements: in uppermost Triassic and Lower Jurassic fine-grained deposits of the Polish Basin (P. Brański and S.M. Mikulski), and in the youngest Pleistocene glacial tills in Poland (P. Kwecko).

The final four papers in this issue deal with Roztocze (SE Poland) and the Carpathian Foredeep Basin. The location of this set of papers in this issue reflects that these have been the last basins extensively studied by Piotr Roniewicz. P. Gedl reports Homotryblium-dominated
Eocene dinoflagellate cyst assemblages from basal parts of the Middle Miocene (Badenian) glauconitic sands at Lipowiec (Roztocze). N. Oszczypko et al. characterize the Stebnyk Formation (Miocene) in the Boryslav-Pokuttya and Sambir nappes of the Ukrainian Carpathians, and this paper completes the picture of the evolution of the foreedep basin, the earlier stages of which are presented by the authors in two previous publications, in Geological Quarterly, A. Głuszyński and $P$. Aleksandrowski discuss the control on facies of Badenian (Middle Miocene) evaporites, exerted by a deep palaeovalley in the floor of the Carpathian Foredeep Basin near Pilzno, and P. Gedl et al. show that some discrepancies observed between foraminifera and palynomorphs studied from the same set of samples coming from the Upper Badenian deposits at Anadoly (marginal part of the Ukrainian Carpathian Foredeep Basin) remain enigmatic. This issue is concluded by the report by $\mathrm{G}$. Racki on influential Polish publications in sedimentary geology in 1996-2016.

To Piotr Roniewicz, geology, sedimentology in particular, has always been a fascinating journey through the events that have once shaped the surface of the Earth. His substantial impact on the understanding of sedimentology in Poland is perfectly expressed in the long list of contributors of this issue - both his former students and sedimentologists from other institutions that are under the strong influence of his ideas. We strongly hope that the contributions presented in this issue will be met with his friendly reception.

Anna Wysocka and Tadeusz Marek Peryt 